\title{
Relationship between respiratory quotient, nitrification, and nitrous oxide emissions in a forced aerated composting process
}

Hirofumi Tsutsui ${ }^{\text {a,e* }}$, Taku Fujiwara ${ }^{\text {a, e }}$, Daisuke Inoue ${ }^{\text {b, e }}$, Ryusei Ito ${ }^{\text {c, e }}$, Kazutsugu Matsukawa ${ }^{\text {d,e }}$, Naoyuki Funamizu ${ }^{\text {ce }}$

${ }^{a}$ Research and Education Faculty, Natural Sciences Cluster, Agriculture Unit, Kochi University, B200 Monobe, Nankoku, Kochi, Japan

${ }^{\mathrm{b}}$ Department of Health Science, School of Allied Health Sciences, Kitasato University, 1-15-1

Kitasato, Sagamihara-Minami, Kanagawa, Japan

${ }^{c}$ Department of Environmental Engineering, Graduate School of Engineering, Hokkaido University, Kita-13, Nishi-8, Kita-ku, Sapporo, Hokkaido, Japan

${ }^{\mathrm{d}}$ Research and Education Faculty, Multidisciplinary Science Cluster, Life and Environmental Medicine Science Unit, Kochi University, B200 Monobe, Nankoku, Kochi, Japan

e Japan Science and Technology Agency, CREST, Japan

*Corresponding author

Hirofumi Tsutsui

Research and Education Faculty, Natural Sciences Cluster, Agriculture Unit, Kochi University B200 Monobe, Nankoku, Kochi, Japan

Tel/Fax: +81-88-864-5163

E-mail: jm-tsutsuih@kochi-u.ac.jp 


\begin{abstract}
We assessed the relationship between respiratory quotient (RQ) and nitrification and nitrous oxide $\left(\mathrm{N}_{2} \mathrm{O}\right)$ emission in forced aerated composting using lab-scale reactors. Relatively high RQ values from degradation of readily degradable organics initially occurred. RQ then stabilized at slightly lower values, then decreased. Continuous emission of $\mathrm{N}_{2} \mathrm{O}$ was observed during the RQ decrease. Correlation between nitrification and $\mathrm{N}_{2} \mathrm{O}$ emission shows that the latter was triggered by nitrification. Mass balances demonstrated that the $\mathrm{O}_{2}$ consumption of nitrification ( $\left.24.8 \mathrm{mmol}\right)$ was slightly higher than that of $\mathrm{CO}_{2}$ emission $(\sim 20.0 \mathrm{mmol})$, indicating that the RQ decrease was caused by the occurrence of nitrification. Results indicate that RQ is a useful index, which not only reflects the bioavailability of organics but also predicts the occurrence of nitrification and $\mathrm{N}_{2} \mathrm{O}$ emission in forced aerated composting.
\end{abstract}




\section{Introduction}

The spreading of livestock excrement can contribute to nitrate contamination of groundwater and eutrophication of surface waters. To mitigate these issues, a decentralized differentiable treatment system for livestock excreta that discharges minimum pollutants, produces minimal greenhouse gas (GHG) emissions, and more effectively recovers nutrients has been proposed (Fujiwara, 2012). Producing compost of better quality and less GHG emission is one of the key technologies in this innovative system, through preventing environmental pollution and enhancing resource recycling in agricultural areas. To achieve these outcomes, it is necessary to understand changes of the material during the composting process. In particular, the emission of nitrous oxide $\left(\mathrm{N}_{2} \mathrm{O}\right)$, which is a $\mathrm{GHG}$ and has a reported global warming potential 298 times greater than that of carbon dioxide $\left(\mathrm{CO}_{2}\right)$ (IPCC, 2007), has become a problem in agricultural areas. Controls are needed to reduce $\mathrm{N}_{2} \mathrm{O}$ emissions produced during the composting process.

Compost stability is an important component of the composting process, because it has implications for compost use as a fertilizer. Stability is related to the types of organic compounds that remain following composting and the microbial activity of composted materials (California Compost Quality Council, 2001). The primary goal of composting is to produce a stabilized end-product (Komilis and Kanellos, 2012). Some of the most common compost stability tests are based on quantification of microbial respiration (Komilis et al., 2011a). Microbial respiration activity indices based on oxygen $\left(\mathrm{O}_{2}\right)$ uptake rate (OUR) such as AT4 (static respiration index for 4 days) 
and specific OUR (SOUR) (Lasaridi et al., 2006), and on $\mathrm{CO}_{2}$ evolution (Bernal et al., 2009), are

commonly used to test compost stability (Gómez et al., 2006). By coupling data of OUR and $\mathrm{CO}_{2}$

evolution rates, the respiratory quotient (RQ) can be calculated. The RQ is the ratio of the number of moles of $\mathrm{CO}_{2}$ generated to the number of moles of $\mathrm{O}_{2}$ consumed. The value of RQ is known to reflect not only microbial respiration but also the biochemical composition of organic material (Gea et al., 2004), and is widely used in the study of soil environments (Dilly, 2003). Previous studies have reported that RQ is a useful index for composting processes (Atkinson et al., 1997), although others reported that RQ did not change significantly throughout those processes (Gea et al., 2004; Gómez et al., 2006). The applicability of RQ as an index of compost stability requires further study. Stability indices are not only important measures of compost characteristics, but can also be used for process performance monitoring (Gómez et al., 2006). It is important to establish useful indices for both measuring compost stability and monitoring microbial reactions during composting, to identify appropriate conditions that will produce high-quality compost while lowering GHG emissions. To reduce $\mathrm{N}_{2} \mathrm{O}$ emissions from the composting process, microbial activity in the nitrogen cycle during nitrogen transformation should be monitored. Previous studies of respiration indices such as RQ in composting processes have only focused on the biochemical composition of organic material (Gea et al., 2004; Komilis and Kanellos, 2012). In an earlier study, we constructed experimental devices for continuous monitoring of emitted gases from a composting reactor, indicating that $\mathrm{N}_{2} \mathrm{O}$ emissions occurred simultaneously with an RQ decrease (Tsutsui et al., 2013). 
However, we could not obtain information about potential mechanisms responsible for this relationship, because we did not conduct either microbial community or mass balance analyses.

In this study, we took a two-step approach to examine RQ usefulness as an indicator, for both compost stability and monitoring of nitrification and $\mathrm{N}_{2} \mathrm{O}$ emissions. In the first step, we performed a detailed gas-phase analysis to clarify the relationship between the RQ decrease and $\mathrm{N}_{2} \mathrm{O}$ emissions. We used lab-scale forced aerated composting reactors to continuously measure gas components, toward evaluating the suitability of RQ as an indicator. In this experiment, we did not conduct sampling campaigns to avoid the variation of gas components triggered by sample mixing for clarifying the relationship between the RQ decrease and $\mathrm{N} 2 \mathrm{O}$ emissions. In the second step, we investigated mechanisms responsible for the simultaneous occurrence of nitrification and $\mathrm{N}_{2} \mathrm{O}$ emissions with the RQ decrease in the forced aerated composting process. This was done by conducting gas phase, sample composition, microbial community, and mass balance analyses. In addition, temporally and spatially complex environment conditions (such as temperature, oxygen concentration, and water content) make us difficult to clear the mechanism of $\mathrm{N}_{2} \mathrm{O}$ emission in actual composting process. To achieve the objective of our study, we conducted the forced aerated composting process under isothermal condition and maintained the water content at constant to prevent the effect of large fluctuation in environmental conditions.

\section{Materials and Methods}

\subsection{Composting reactors and experimental devices}


Composting reactors and experimental devices used were described in detail by Tsutsui et al.

(2013). Briefly, we used three 1.63-L forced aerated composting reactors equipped with a porous stainless steel plate at the bottom. Inlet gas was humidified to maintain water content of the samples at $\sim 60 \%$. Outlet gas was bubbled into a $5 \mathrm{mM}$ sulfuric acid solution to trap ammonia gas. To express the measured gas concentration in the inlet and outlet as the molar flow rate $(\mathrm{mmol} / \mathrm{h})$ at standard conditions (273.15 K; $101.325 \mathrm{kPa})$, temperature and pressure sensors (Sensez, Tokyo, Japan) and a gas flow meter RK1150PV (Kojima Instruments Inc., Kyoto, Japan) were placed upstream and downstream of the reactor, respectively. Solenoid valves were installed downstream of the sensors in the outlet gas line to guide exhaust gas into the gas analysis devices by turns.

\subsection{Composting experiments}

Manure from Japanese brown cattle raised at Kochi University (Kochi, Japan) and dried sawdust of Japanese cedar and Japanese cypress trees were used as composting materials. Fresh manure from four cattle was sampled and mixed well, then immediately transferred to the laboratory and processed in preparation for analysis of water content. Manure samples were used in the experiment within 12 hours of collection.

Sawdust was added to the cattle manure to adjust moisture content to $60 \%$, and the well-mixed sawdust and manure were transferred to the composting reactors. Reactors were submerged in water baths controlled at $30{ }^{\circ} \mathrm{C}$ and inlet air was supplied to the reactor to start the 
composting experiment. Gas flow rate and pressure were controlled and kept constant at 1.7

$\mathrm{ml} / \mathrm{min} / \mathrm{g}-\mathrm{TS}$ and $161.6-167.7 \mathrm{kPa}$ throughout the experiment, using a needle valve and pressure

regulator, respectively.

\subsubsection{Relationship between $\mathrm{RQ}$ and $\mathrm{N}_{2} \mathrm{O}$ emission (Experiment I)}

To ensure reproducibility of the relationship between RQ and occurrence of $\mathrm{N}_{2} \mathrm{O}$ emission

observed in the earlier study (Tsutsui et al., 2013), we conducted a forced aerated composting

experiment (Experiment I) and monitored RQ and $\mathrm{N}_{2} \mathrm{O}$ emission rates. To get clear gas component data, we did not do sampling during Experiment I, because variation of gas components was triggered by sampling of the composting mixture.

Sawdust (120.6 g) was added to the cattle manure (429.4 g) to adjust moisture content to $60 \%$. Then, $550 \mathrm{~g}$ of the well-mixed sawdust and manure were transferred to the three composting reactors. Inlet air was then continuously supplied to the reactor for 30 days. During Experiment I, $\mathrm{RQ}$ and $\mathrm{N}_{2} \mathrm{O}$ emission rates were monitored by following the steps in Section 2.4. Characteristics of the composting samples at the beginning and end of experiment are listed in Table 1.

\subsubsection{Mechanisms of $R Q$ decrease and $\mathrm{N}_{2} \mathrm{O}$ emission (Experiment II)}

To clarify mechanisms responsible for the simultaneous RQ decrease and occurrence of $\mathrm{N}_{2} \mathrm{O}$ emission, a forced aerated composting experiment was executed (Experiment II). Sawdust (39.6 g) was added to the cattle manure $(235.4 \mathrm{~g})$ to adjust moisture content to $60 \%$. Then, $275 \mathrm{~g}$ of the well-mixed sawdust and manure were transferred to the two composting reactors 1 and 2. Inlet air 
was then continuously supplied to the reactor for 44 days. A portion of the composting mixture was collected on days $2,5,15,20,24,26,29$, and 32 . Before sampling, contents of each reactor were well mixed and total weight was measured. After sampling, the contents were returned to the reactor to simulate a pile mixing. The amount of sampling per sampling day depended on the measurement items and ranged from $3 \mathrm{~g}$-wet to $10 \mathrm{~g}$-wet (4.2 g-wet on average). Collected samples were processed for chemical and microbial community analysis, described in Sections 2.3 and 2.5, respectively. Additionally, gas analyses were done during the experiment by following the steps in Section 2.4.

\subsection{Chemical analysis}

Moisture content and total solid (TS) content of the samples were calculated from weights obtained before and after drying at $105^{\circ} \mathrm{C}$ for $12 \mathrm{~h}$. The dried samples were processed at $600{ }^{\circ} \mathrm{C}$ for $2 \mathrm{~h}$ to calculate the content of volatile solids. We measure the chemical oxygen demand $\left(\mathrm{COD}_{\mathrm{Cr}}\right)$ of composting sample suspended in ultrapure water by using COD reagent TNT822 (HACH, Loveland, CO, USA) to assess the biodegradation of organic matter contained in composting samples.

Measurements of $\mathrm{NH}_{4}{ }^{+}-\mathrm{N}, \mathrm{NO}_{2}{ }^{-}-\mathrm{N}$, and $\mathrm{NO}_{3}{ }^{-}-\mathrm{N}$ concentrations in the composting mixture were made by following the methods in Tsutsui et al. (2013). Samples for $\mathrm{pH}$ measurement were prepared by shaking (200 rpm, $30 \mathrm{~min}$ ) after adding distilled water in a volume equivalent to 10 times of the TS weight, and calibrated electrodes (Horiba, Kyoto, Japan) were used for $\mathrm{pH}$ analysis. Total carbon 
and total nitrogen were determined by gas chromatography with an N-C analyzer (SUMIGRAPH NC-1000; Sumika Chemical Analysis Service, Ltd., Osaka, Japan).

\subsection{Gas analysis}

Average gas molar flow rates for 60 min were used for the following OUR analysis.

Concentrations of $\mathrm{O}_{2}, \mathrm{CO}_{2}$, and $\mathrm{N}_{2} \mathrm{O}$ in inlet and outlet gas were measured and expressed as the molar flow rate $(\mathrm{mmol} / \mathrm{h})$ at standard conditions $(273.15 \mathrm{~K} ; 101.325 \mathrm{kPa})$, as in the methods of Tsutsui et al. (2013). Oxygen concentration, gas pressure, and gas temperature of the input and output were measured every $1 \mathrm{~min}$, and OUR was calculated from the $\mathrm{O}_{2}$ molar flow rate in the inlet and outlet gas, using the following equation (Lopez Zavala et al., 2004).

$$
\operatorname{OUR}\left(\mathrm{mmol} \bullet \mathrm{h}^{-1}\right)=\left(\left[\mathrm{O}_{2}\right]_{\text {in }}-\left[\mathrm{O}_{2}\right]_{\text {out }}\right)
$$

where $\left[\mathrm{O}_{2}\right]_{\text {in }}$ and $\left[\mathrm{O}_{2}\right]_{\text {out }}$ are input and output of $\mathrm{O}_{2}$ molar flow rates $\left(\mathrm{mmol} \cdot \mathrm{h}^{-1}\right)$, respectively. Concentrations of $\mathrm{CO}_{2}$ and $\mathrm{N}_{2} \mathrm{O}$ in the outlet gas were measured three times within 30 min at the outlet of each reactor, using a micro-GC GC-490 (GL Sciences, Tokyo, Japan). Additionally, $\mathrm{CO}_{2}$ concentration in the laboratory air was monitored with a $\mathrm{CO}_{2}$ sensor $\mathrm{MCH}-383 \mathrm{SD}$ (Sato Co., Tokyo, Japan) installed at the air inlet port, to correct the $\mathrm{CO}_{2}$ concentration derived from inlet air. The RQ was calculated using the following equation (Atkinson et al., 1997).

$$
\mathrm{RQ}(-)=\frac{\mathrm{CO}_{2} \text { emission }(\mathrm{mol})}{\mathrm{O}_{2} \text { consumption }(\mathrm{mol})}
$$


Cumulative values of $\mathrm{CO}_{2}$ emission and $\mathrm{O}_{2}$ consumption were used for the calculation of $\mathrm{RQ}$.

Duration for the calculation for cumulative values of $\mathrm{CO}_{2}$ and $\mathrm{O}_{2}$ were 30 min. in Experiment I and 6

$\mathrm{h} \sim 36 \mathrm{~h}$ in Experiment II.

\subsection{Microbial community analysis}

\subsubsection{DNA extraction and purification}

For microbial community analyses, DNA was extracted from approximately $0.2 \mathrm{~g}$ of wet compost samples using the ISOIL for Beads Beating kit (Nippon Gene, Tokyo, Japan) and further purified with a MagExtractor-PCR \& Gel Clean up (Toyobo, Osaka, Japan) according to manufacturer's instructions.

2.5.2 Real-time PCR quantification of 16S rRNA genes of eubacteria and amoA genes of ammonia oxidizing bacteria $(A O B)$

Real-time PCR quantifications of 16S rRNA genes of total eubacteria and amoA genes of ammonia oxidizing bacteria (AOB) were carried out on a PikoReal real-time PCR system (Thermo Scientific, Waltham, MA, USA), using a GeneAce SYBR qPCR Mix a (Nippon Gene, Tokyo, Japan). Primers SRV3-1 and SRV3-2 (Lee et al., 1996) were used for quantification of 16S rRNA gene numbers, whereas primers amoA-1F and amoA-2R (Rotthauwe et al., 1997) were used for quantification of $\mathrm{AOB}$ amoA gene numbers. The reaction mixture $(20 \mu \mathrm{l})$ contained $1 \times$ GeneAce SYBR qPCR Mix $\alpha, 0.2 \mu \mathrm{M}$ of each primer, and $2 \mu \mathrm{l}$ of DNA template. The thermal profile for 
quantification of $16 \mathrm{~S}$ rRNA genes consisted of initial enzyme activation at $95{ }^{\circ} \mathrm{C}$ for $10 \mathrm{~min}$, then 40 cycles of denaturation at $95{ }^{\circ} \mathrm{C}$ for $30 \mathrm{~s}$ and annealing and extension at $60{ }^{\circ} \mathrm{C}$ for $1 \mathrm{~min}$. The thermal profile for $\mathrm{AOB} a m o A$ gene quantification consisted of initial enzyme activation at $95{ }^{\circ} \mathrm{C}$ for $10 \mathrm{~min}$, followed by 40 cycles of denaturation at $95{ }^{\circ} \mathrm{C}$ for $30 \mathrm{~s}$, annealing at $60^{\circ} \mathrm{C}$ for $30 \mathrm{~s}$, and extension at $72{ }^{\circ} \mathrm{C}$ for $30 \mathrm{~s}$. After the aforementioned PCR and subsequent hold at $60{ }^{\circ} \mathrm{C}$ for $30 \mathrm{~s}$, melting curve analyses were performed from $60-95{ }^{\circ} \mathrm{C}$ with a read every $0.2{ }^{\circ} \mathrm{C}$ and hold of $1 \mathrm{~s}$ between reads. Standard curves for 16S rRNA genes and AOB amoA genes were prepared using serial dilutions of genomic DNA from Escherichia coli NBRC 12713 and Nitrosomonas europaea NBRC 14298), respectively, concentrations of which were determined using a Qubit dsDNA HS Assay kit (Life Technologies/Molecular Probes, Eugene, OR, USA) with Qubit 2.0 fluorometer (Life Technologies/Invitrogen, Carlsbad, CA, USA). All quantifications were done in triplicate. PCR efficiencies for $16 \mathrm{~S}$ rRNA genes and AOB amoA genes were $83.9 \%$ and $81.0 \%$, respectively.

\subsubsection{PCR detection of amoA genes of ammonia oxidizing archaea (AOA)}

The presence of ammonia oxidizing archaea (AOA) amoA genes was examined by conventional PCR using primers Arch-amoAF and Arch-amoAR (Francis et al., 2005) in a T100 thermal cycler (Bio-Rad Laboratories, Hercules, CA, USA). The reaction mixture (50 $\mu$ l) consisted of $1 \times$ SapphireAmp Fast PCR Master Mix (Takara Bio, Shiga, Japan), $0.2 \mu \mathrm{M}$ of each primer, and 2 $\mu l$ of DNA template. The thermal profiles consisted of initial enzyme activation and denaturation at $95{ }^{\circ} \mathrm{C}$ for $5 \mathrm{~min}, 40$ cycles of denaturation at $94{ }^{\circ} \mathrm{C}$ for $45 \mathrm{~s}$, annealing at $53-58{ }^{\circ} \mathrm{C}$ for $1 \mathrm{~min}$, 
extension at $72{ }^{\circ} \mathrm{C}$ for $1 \mathrm{~min}$, and final extension at $72{ }^{\circ} \mathrm{C}$ for $15 \mathrm{~min}$. PCR products were analyzed

by electrophoresis on a $1.5 \%$ (w/v) agarose gel stained with SYBR Green I (Takara Bio, Shiga,

Japan).

\section{Results and discussion}

\subsection{Relationship between RQ value and $\mathrm{N}_{2} \mathrm{O}$ emission in Experiment $\mathrm{I}$}

Profiles of the OUR and $\mathrm{CO}_{2}$ emissions from the triplicate composting reactors are shown in Fig. 1(A) and (B), respectively. Small standard deviations of the OUR or $\mathrm{CO}_{2}$ emission profiles throughout the experiment demonstrate good reproducibility of organic matter decomposition in this experiment. Additionally, the profile of $\mathrm{CO}_{2}$ emission rates was similar to that of OUR in all reactors, with relatively low values. In the first hour of the experiment, OUR and $\mathrm{CO}_{2}$ emission rates were maxima; they then decreased, with two narrow peaks at $5.5 \mathrm{~h}$ and $20.5 \mathrm{~h}$. Relatively stable OUR values were observed from days 2 through 7 . OUR values began to decrease from $\sim 6.5$ (day 7 ) to $\sim 5.0 \mathrm{mmol} / \mathrm{h}$ (day 9). Simultaneously, $\mathrm{CO}_{2}$ emission rates began to decline from about 2.3 (day 7) to about $0.80 \mathrm{mmol} / \mathrm{h}$ (day 9). Beginning on day 9, a gradual decline in OUR and $\mathrm{CO}_{2}$ emission rates was observed, which continued until the end of the experiments (day 29.5). The thresholds of OUR and $\mathrm{CO}_{2}$ emission rates for composting stability are proposed to be $0.4 \mathrm{~g}-\mathrm{O}_{2} / \mathrm{g}-\mathrm{TS} / \mathrm{h}$ and 2 g- $\mathrm{CO}_{2} / \mathrm{g}-\mathrm{VS} /$ day, respectively (California Compost Quality Council, 2001). In our study, OUR and $\mathrm{CO}_{2}$ emission rates at the end of experiment were $0.31 \mathrm{~g}-\mathrm{O}_{2} / \mathrm{g}-\mathrm{TS} / \mathrm{h}$ and $0.22 \mathrm{~g}-\mathrm{CO}_{2} / \mathrm{g}-\mathrm{VS} / \mathrm{day}$, respectively. These results indicate that the end product of the experiments was stabilized compost. 
Changes in RQ values and $\mathrm{N}_{2} \mathrm{O}$ emission rates over the course of Experiment I are shown in

Fig. 1(C) and (D), respectively. At the beginning of the experiment, a rapid decrease in RQ was observed, followed by stable values around 0.35 from day 2 through 7 . An RQ decrease over time has been observed in other studies (Komilis et al., 2011b) and the initial decomposition of readily degradable material, followed by decomposition of remaining moderately and slowly degradable organic material, was expected to affect such behavior (Komilis et al., 2011b). After the stable period, RQ declined drastically from 0.35 on day 7 to 0.13 on day $10 . \mathrm{N}_{2} \mathrm{O}$ emissions began to increase dramatically from day 7 through 10 in all three reactors, then gradually decreased until day 20 . A temporal shift of correlation between RQ and $\mathrm{N}_{2} \mathrm{O}$ emission rates is plotted in Fig. 2. The shift of the plots to the upper left side of the figure from day 7 through 11 shows that $\mathrm{N}_{2} \mathrm{O}$ emission rates increased as RQ decreased. Stable and low RQ values in the final five days of the experiments, which were demonstrated by the stable OUR and $\mathrm{CO}_{2}$ emission rates, indicate that there was adequate degradation of organic matter in the composting sample and low risk of $\mathrm{O}_{2}$ depletion when the end product was applied to agricultural field soil.

\subsection{RQ and $\mathrm{N}_{2} \mathrm{O}$ emissions in Experiment II}

RQ values and $\mathrm{N}_{2} \mathrm{O}$ emission rates during Experiment II are shown in Fig. 3(A) and (B), respectively. Relatively wide variations of $\mathrm{RQ}$ and $\mathrm{N}_{2} \mathrm{O}$ emission rates were observed in this experiment. This might be a result of the sampling process; decomposition of organic matter and 
$\mathrm{CO}_{2}$ emissions are enhanced by mixing of the composting sample. To identify the RQ trend more clearly, the 3-day moving average line is shown in Fig. 3(A). The RQ trend in Experiment II was generally similar to that of Experiment I, i.e., RQ decreased rapidly at the beginning of the experiment, then stabilized from day 5 through 15, and decreased again from day 15 through 23 . However, relatively high $\mathrm{N}_{2} \mathrm{O}$ emissions were observed from day 17 through 28 . Although the peak $\mathrm{N}_{2} \mathrm{O}$ emission occurred 7 days later than in Experiment I, the RQ decrease and $\mathrm{N}_{2} \mathrm{O}$ emissions were observed in nearly the same period in Experiment II. These results and those of our previous study (Tsutsui et al., 2013) indicate that the RQ decrease and $\mathrm{N}_{2} \mathrm{O}$ emissions occurred over the same period. Furthermore, highest $\mathrm{N}_{2} \mathrm{O}$ emission rate in Experiment II was much lower than that in Experiment I. Amount of composting sample in Experiment I was twice as much as that in Experiment II. And the amount of $\mathrm{NO}_{3}{ }^{-} \mathrm{N}$ at the end of experiment I was about 1.5 times as much as that in Experiment II. In addition, we mixed the composting sample only in Experiment II. Those differences might affect the $\mathrm{N}_{2} \mathrm{O}$ emission rate.

\subsection{Mechanism of $\mathrm{N}_{2} \mathrm{O}$ emission}

Figure 4 shows the behavior of inorganic nitrogen in the composting samples during

Experiment II. The decrease in $\mathrm{NH}_{4}{ }^{+}-\mathrm{N}$ at the beginning of that experiment was induced by ammonia volatilization, and the increase in $\mathrm{NH}_{4}{ }^{+}-\mathrm{N}$ from day 2 through 20 may have resulted from degradation of organic matter (Guo et al., 2012). From day $15, \mathrm{NO}_{2}{ }^{-}-\mathrm{N}_{\text {and }} \mathrm{NO}_{3}{ }^{-}-\mathrm{N}$ began to 
increase and reached $130 \mathrm{mg}-\mathrm{N}$ and $436 \mathrm{mg}-\mathrm{N}$ on day 24 and day 29, respectively, indicating nitrification between day 15 and 29. Cumulative $\mathrm{O}_{2}$ consumption for the production of $\mathrm{NO}_{2}{ }^{-}-\mathrm{N}$ and $\mathrm{NO}_{3}{ }^{-}-\mathrm{N}$ calculated by the amount of $\mathrm{NO}_{2}{ }^{-}-\mathrm{N}$ and $\mathrm{NO}_{3}{ }^{-}-\mathrm{N}$ in composting sample from day 20 through 26 was $24.8 \mathrm{mmol}$, and was slightly higher than that for $\mathrm{CO}_{2}$ emission. In general, the amount of $\mathrm{O}_{2}$ uptake by nitrifier is much lower than the amount of $\mathrm{O}_{2}$ uptake by heterotrophic microorganisms. This might be because easily degradable organics was already consumed during the beginning period (Fig. 1C), and $\mathrm{O}_{2}$ consumption by heterotrophs for $\mathrm{CO}_{2}$ production was significantly decreased. Combined with the coincidence in time in the decline of RQ and the increase of $\mathrm{N}_{2} \mathrm{O}$, the decrease of RQ was induced by both a reduction in the availability of organic material and in $\mathrm{O}_{2}$ consumption for nitrification. Both inorganic nitrogen content and RQ finally stabilized after day 32, as shown in Figs. 3(A) and 4. The decrease in $\mathrm{O}_{2}$ consumption by nitrification resulted in a stable RQ value in the later period of the composting process. These results indicate the usefulness of RQ as an index for monitoring the occurrence and end of nitrification. Finally, $\mathrm{NO}_{3}{ }^{-}-\mathrm{N}$ content in the composting sample (377 mg-N) was much higher than $\mathrm{NH}_{4}{ }^{+} \mathrm{N}(59.5 \mathrm{mg}-\mathrm{N})$ and $\mathrm{NO}_{2}{ }^{-}-\mathrm{N}(38.6 \mathrm{mg}-\mathrm{N})$.

Nitrogen balance during Experiment II is shown in Table 2. Although the proportion of total nitrogen occurring as organic nitrogen was high (85.2\%) at the beginning of that experiment, this decreased to about half the total nitrogen $(54.7 \%)$ at the experiment end, because of the degradation of organic matter. That is, about half the nitrogen in the samples was inert during the composting process. A decrease of organic nitrogen was caused by transformation to inorganic nitrogen 
(26.9\%/initial T-N), a portion of which was emitted as $\mathrm{NH}_{3}\left(17.1 \%\right.$ /initial T-N) and $\mathrm{N}_{2} \mathrm{O}$

(2.02\%/initial T-N) through the end of the experiment. Emission rates of $\mathrm{N}_{2} \mathrm{O}$ in this and earlier studies are summarized in Table 3. The $\mathrm{N}_{2} \mathrm{O}$ emission rate in Experiment II was relatively low but within the range of reported values. The data shown in Table 2 indicate that denitrification was negligible during this experiment. Therefore, correlation of oxidized nitrogen $\left(\mathrm{NO}_{2}{ }^{-} \mathrm{N}+\mathrm{NO}_{3}{ }^{-}-\mathrm{N}\right)$ and $\mathrm{N}_{2} \mathrm{O}$ emissions between sampling dates are plotted in Fig. 5. These plots are used to investigate the relationship between nitrification and $\mathrm{N}_{2} \mathrm{O}$ emission rates in Experiment II. A strong linear relationship between the two implies that nitrification was the dominant pathway for $\mathrm{N}_{2} \mathrm{O}$ emission in these experiments. The slope of the collinear approximation indicates that $\sim 2.7 \%$ of oxidized ammonia might be converted to $\mathrm{N}_{2} \mathrm{O}$ during composting. In Experiments I and II, we observed a clear relationship between the RQ decrease, nitrification, and $\mathrm{N}_{2} \mathrm{O}$ emission rates under forced aeration composting. Therefore, we conclude that RQ is a useful index, reflecting not only the bioavailability of residual organics but also predicting nitrification and $\mathrm{N}_{2} \mathrm{O}$ emissions in aerobic composting.

To obtain microbial evidence for nitrogen metabolism in Experiment II, abundance of the amoA gene of AOB and AOA was measured. Transition of the amoA gene of AOB and 16S rRNA gene of eubacteria are shown in Fig. 6. Abundance of the 16S rRNA gene of eubacteria was relatively stable; it increased slightly during the first half of the period (through day 15) and decreased slightly in the second half (Fig. 6). Growth and decrease of eubacteria might result from 
degradation of readily biodegradable organic matter and endogenous respiration of heterotrophic microorganisms, respectively (Hotta and Funamizu, 2007). Abundance of the amoA gene of AOB was below detection limits $\left(4.6 \times 10^{3}\right.$ copies/g-TS $)$ in both reactors at the beginning of the experiment. However, the amoA gene of AOB was detected from day 15 , reaching $3.0 \times 10^{5}$ copies/g-TS in reactor 1 and $9.8 \times 10^{5}$ copies/g-TS in reactor 2 on day 29 . These results indicate that growth of AOB with nitrification occurred in Experiment II. The abundance of the amoA gene of AOB was nearly the same as that reported in other studies on swine slurry composting (Angnes et al., 2013) and beef and dairy cow manure compost (Yamada et al., 2013), but much lower than that observed in dairy cow manure compost (about $10^{7}-10^{9}$ copies/g-TS) (Maeda et al., 2010). The abundance of AOB is expected to vary between different compost types because of the difference in sample components or bedding material. The abundance of $\mathrm{AOB}$ in our experiment was equivalent to the average abundance found across a variety of compost types. Ammonia oxidization activity by AOA has been a focus of recent research, and studies have reported that AOA was either present in composting processes (Yamamoto et al., 2010; Zeng et al., 2011; Xie et al., 2012) or the key community for ammonia oxidization (Zhang et al., 2011). We investigated the presence of AOA amoA genes by conventional PCR. Although we used a widely used primer set and modified PCR conditions, non-specific amplification was observed in all DNA samples (data not shown). Although we could not determine the abundance of the amoA gene of AOA in the present study, a very weak band with the anticipated size for the target amoA gene of AOA was detected only on day 5 in reactor 1 . 
Therefore, the abundance of AOA in Experiment II was low, whereas AOB appears to be predominantly responsible for the observed nitrification activity. This might be because our experiment was conducted at $30{ }^{\circ} \mathrm{C}$ to encourage bacterial activity, especially that related to the nitrogen cycle. As a result, activity of AOB exceeded that of AOA.

\section{Conclusion}

We assessed the relationship between RQ, nitrification, and $\mathrm{N}_{2} \mathrm{O}$ emission in a forced aerated composting process using lab-scale reactors. Continuous emissions of $\mathrm{N}_{2} \mathrm{O}$ were observed during a decrease in RQ. Mass balance calculations demonstrated that nitrification occurrence caused the latter decrease. Correlation between nitrification and $\mathrm{N}_{2} \mathrm{O}$ emission shows that nitrification triggered that emission. Our results indicate that RQ is a useful index, predicting the occurrence of nitrification and $\mathrm{N}_{2} \mathrm{O}$ emission during forced aerated composting of cattle manure under isotherm condition. These findings may contribute to producing compost with improved quality and fewer GHG emissions.

\section{Acknowledgements}

This research was financially supported by the Core Research for Evolutionary Science and Technology (CREST) of the Japan Science and Technology Agency. The authors wish to thank Dr. Nowaki Hijikata of Hokkaido University for his assistance with the instrumental analyses. 


\section{Reference}

Ahn, H.K., Mulbry, W., White, S. L., Kondrad, S.L., 2011. Pile mixing increases greenhouse gas emissions during composting of dairy manure. Bioresour. Technol. 102, 2904-2909.

Angnes, G., Nicoloso, R.S., da Silva, M.L., de Oliveira, P.A., Higarashi, M.M., Mezzari, M.P., Miller, P.R., 2013. Correlating denitrifying catabolic genes with $\mathrm{N}_{2} \mathrm{O}$ and $\mathrm{N}_{2}$ emissions from swine slurry composting. Bioresour. Technol. 140, 368-375.

Atkinson, C.F., Jones, D.D., and Gauthier, J.J., 1997. Microbial activities during composting of pulp and paper-mill primary solids. World J. Microbiol. Biotechnol. 13, 519-525.

Bernal, M.P., Alburquerque, J.A., and Moral, R., 2009. Composting of animal manures and chemical criteria for compost maturity assessment. A review. Bioresour. Technol. 100, $5444-5453$.

California Compost Quality Council (CCQC), 2001. Compost Maturity Index, Technical Report.

Chowdhury, M.A., de Neergaard, A., Jensen, L.S., 2014. Potential of aeration flow rate and bio-char addition to reduce greenhouse gas and ammonia emissions during manure composting. Chemosphere. 97, 16-25.

Dilly, O., 2003. Regulation of the respiratory quotient of soil microbiota by availability of nutrients. FEMS Microbiol. Ecol. 43, 375-381. 
Francis, C.A., Roberts, K.J., Beman, J.M., Santoro, A.E., Oakley, B.B., 2005. Ubiquity and diversity of ammonia-oxidizing archaea in water columns and sediments of the ocean. Proc. Natl. Acad. Sci. USA. 102, 14683-14688.

Fujiwara, T., 2012. Concept of an innovative water management system with decentralized water reclamation and cascading material-cycle for agricultural areas, Water Sci. Technol. 66, $1171-1177$.

Fukumoto, Y., Suzuki, K., Osada, T., Kuroda, K., Hanajima, D., Yasuda, T., Haga, K., 2006. Reduction of nitrous oxide emission from pig manure composting by addition of nitrite-oxidizing bacteria. Env. Sci. Technol. 40(21), 6787-6791.

Fukumoto, Y., Osada, T., Hanajima, D., Haga, K., 2003. Patterns and quantities of $\mathrm{NH}_{3}, \mathrm{~N}_{2} \mathrm{O}$ and $\mathrm{CH}_{4}$ emissions during swine manure composting without forced aeration-effect of compost pile scale. Bioresour. Technol. 89, 109-114.

Fukumoto, Y., Inubushi, K., 2009. Effect of nitrite accumulation on nitrous oxide emission and total nitrogen loss during swine manure composting. Soil Sci. Plant Nutri. 55, 428-434.

Fukumoto, Y., Suzuki, K., Kuroda, K., Waki, M., Yasuda, T., 2011. Effects of struvite formation and nitratation promotion on nitrogenous emissions such as $\mathrm{NH}_{3}, \mathrm{~N}_{2} \mathrm{O}$ and $\mathrm{NO}$ during swine manure composting. Bioresour. Technol. 102, 1468-1474. 
Gea, T., Barrena, R., Artola, A., Sánchez, A., 2004. Monitoring the biological activity of the composting process: Oxygen uptake rate (OUR), respirometric index (RI), and respiratory quotient (RQ). Biotechnol. Bioeng. 88, 520-527.

Gómez, R.B., Lima, A.S., Ferrer, A.S., 2006. The use of respiration indices in the composting process: a review. Waste Manag. Res. 24, 37-47.

Guo, R., Li, G., Jiang, T., Schuchardt, F., Chen, T., Zhao, Y., Shen, Y., 2012. Effect of aeration rate, $\mathrm{C} / \mathrm{N}$ ratio and moisture content on the stability and maturity of compost. Bioresour. Technol. 112, 171-178.

Hotta, S., Funamizu, N., 2007. Biodegradability of fecal nitrogen in composting process. Bioresour. Technol., 98, 3412-3414.

IPCC. Climate change 2007: the physical science basis, in: Solomon, S., Qin, D., Manning, M., Chen, Z., Marquis, M., Averyt, K.B., Tignor, M., Miller, H.L. (Eds.), Contribution of Working Group I to the Fourth Assessment Report of the Intergovernmental Panel on Climate Change. United Kingdom and New York, USA: Cambridge, UK. p. 996. Available from http://www.ipcc.ch/publications_and_data/ar4/wg1/en/contents.html [Accessed November 2014].

Jarvis, Å., Sundberg, C., Milenkovski, S., Pell, M., Smårs, S., Lindgren, P-E., Hallin, S., 2009. Activity and composition of ammonia oxidizing bacterial communities and emission 
dynamics of $\mathrm{NH}_{3}$ and $\mathrm{N}_{2} \mathrm{O}$ in a compost reactor treating organic household waste. J. Appl.

Microbiol. 106, 1502-1511.

Komilis, D., Kanellos, D., 2012. A modified dynamic respiration test to assess compost stability:

Effect of sample size and air flowrate. Bioresour. Technol. 117, 300-309.

Komilis, D., Kontou, I., Ntougias, S., 2011a. A modified static respiration assay and its

relationship with an enzymatic test to assess compost stability and maturity. Bioresour.

Technol. 102, 5863-5872.

Komilis, D., Evangelou, A., Voudrias, E.A., 2011b. Monitoring and optimizing the cocomposting of dewatered sludge: a mixture experimental design approach. J. Env. Manag. 92, $2241-2249$.

Lasaridi, K., Protopapa, I., Kotsou, M., Pilidis, G., Manios, T., Kyriakou, A., 2006. Quality assessment of composts in the Greek market: the need for standards and quality assurance. J. Env. Manag. 80, 58-65.

Lee, D.-H., Zo, Y.-G., Kim, S.-J., 1996. Nonradioactive method to study genetic profiles of natural bacterial communities by PCR-single-strand-conformation polymorphism. Appl. Env. Microbiol. 62, 3112-3120.

Lopez Zavala, M.A., Funamizu, N., Takakuwa, T., 2004. Modeling of aerobic biodegradation of feces using sawdust as a matrix. Water Resour. 38, 1327-1339. 
Maeda, K., Toyoda, S., Shimojima, R., Osada, T., Hanajima, D., Morioka, R., Yoshida, N., 2010. Source of nitrous oxide emissions during the cow manure composting process as revealed by isotopomer analysis of and $a m o A$ abundance in betaproteobacterial ammonia-oxidizing bacteria. Appl. Env. Microbiol. 76, 1555-1562.

Rotthauwe, J.-H., Witzel, K.-P., Liesack, W., 1997. The ammonia monoozigenase structural gene $a m o A$ as a functional marker: molecular fine-scale analysis of natural ammonia-oxidizing populations. Appl. Env. Microbiol. 63, 4704-4712.

Szanto, G.L., Hamelers, H.V.M., Rulkens, W.H., Veeken, A.H.M., 2007. $\mathrm{NH}_{3}, \mathrm{~N}_{2} \mathrm{O}$ and $\mathrm{CH}_{4}$ emissions during forced aeration composting of straw-rich pig manure. Bioresour. Technol. 98, 2659-2670.

Tsutsui, H., Fujiwara, T., Matsukawa, K., Funamizu, N., 2013. Nitrous oxide emission mechanisms during intermittently aeration composting of cattle manure. Bioresour. Technol. $141,205-211$.

Xie, K., Jia, X., Xu, P., Huang, X., Gu, W., Zhang, F., Yang, S., Tang, S., 2012. Improved composting of poultry feces via supplementation with ammonia oxidizing archaea. Bioresour. Technol. 120, 70-77.

Yamada, T., Araki, S., Ikeda-Ohtsubo, W., Okamura, A., Ueda, H., Ueda, Y., Miyauchi, K., Endo, G., 2013. Community structure and population dynamics of ammonia oxidizers in composting processes of ammonia-rich livestock waste. Syst. Appl. Microbiol. 36, 359-367. 
Yamamoto, N., Otawa, K., Nakai, Y., 2010. Diversity and abundance of ammonia oxidizing bacteria and ammonia-oxidizing archaea during cattle manure composting. Microb. Ecol. 60, $807-815$.

Zeng, G.M., Zhang, J. C., Chen, Y.N., Yu, Z., Yu, M., Li, H., Liu, Z.F., Chen, M., Lu, L.H., Hu, C.X., 2011. Relative contributions of archaea and bacteria to microbial ammonia oxidation differ under different conditions during agricultural waste composting. Bioresour. Technol. 102, 9026-9032.

Zhang, J., Zeng, G., Chen, Y., Yu, M., Yu, Z., Li, H., Yu, Y., Huang, H., 2011. Effects of physico-chemical parameters on the bacterial and fungal communities during agricultural waste composting. Bioresour. Technol. 102, 2950-2956. 


\section{Tables}

Table 1. Characteristics of compost samples prior to (initial) and following (final) the experimental period.

\begin{tabular}{|c|c|c|c|c|c|c|c|c|}
\hline & $\begin{array}{c}\text { Moisture } \\
\%\end{array}$ & $\begin{array}{l}\mathrm{TS} \\
\%\end{array}$ & $\begin{array}{c}\text { VS } \\
\%-\mathrm{TS}\end{array}$ & $\begin{array}{c}\mathrm{NH}_{4}-\mathrm{N} \\
\text { mg-N/kg-TS }\end{array}$ & $\begin{array}{c}\mathrm{NO}_{2}-\mathrm{N} \\
\text { mg-N/kg-TS }\end{array}$ & $\begin{array}{c}\mathrm{NO}_{3}-\mathrm{N} \\
\mathrm{mg}-\mathrm{N} / \mathrm{kg}-\mathrm{TS}\end{array}$ & $\begin{array}{c}\mathrm{pH} \\
-\end{array}$ & $\begin{array}{l}\mathrm{COD}_{\mathrm{Cr}} \\
\mathrm{g} / \mathrm{kg}-\mathrm{TS}\end{array}$ \\
\hline Initial & $60.0 \pm 0.14$ & $40.0 \pm 0.14$ & $94.5 \pm 0.85$ & $652 \pm 0$ & $0.01 \pm 0.007$ & $2.7 \pm 0.21$ & 7.71 & $1198 \pm 19.8$ \\
\hline Final & $60.5 \pm 0.25$ & $39.5 \pm 0.25$ & $91.8 \pm 0.42$ & $197 \pm 56.9$ & $127 \pm 10.6$ & $1573 \pm 80.6$ & 7.99 & $973 \pm 10.6$ \\
\hline
\end{tabular}


Table 2. Mass balance analysis of nitrogen in Experiment II.

\begin{tabular}{ccccc}
\hline Time (day) & 0 & 15 & 29 & 44 \\
\hline Org-N (mg-N) & $1.50 \times 10^{3}$ & $1.20 \times 10^{3}$ & 546 & 575 \\
$\mathrm{NH}_{4}{ }^{+}-\mathrm{N}(\mathrm{mg}-\mathrm{N})$ & 253 & 268 & 91.4 & 59.5 \\
$\mathrm{NO}_{2}{ }^{-}-\mathrm{N}(\mathrm{mg}-\mathrm{N})$ & 0.32 & 0.94 & 61.0 & 38.6 \\
$\mathrm{NO}_{3}{ }^{-}-\mathrm{N}(\mathrm{mg}-\mathrm{N})$ & 6.78 & 2.58 & 436 & 377 \\
$\mathrm{~T}-\mathrm{N}(\mathrm{mg}-\mathrm{N})$ & $1.76 \times 10^{3}$ & $1.47 \times 10^{3}$ & $1.13 \times 10^{3}$ & $1.05 \times 10^{3}$ \\
$\mathrm{NH}{ }_{3}(\mathrm{mg}-\mathrm{N})$ & 0 & 184 & 301 & 301 \\
$\mathrm{~N}_{2} \mathrm{O}(\mathrm{mg}-\mathrm{N})$ & 0 & 8.89 & 32.5 & 35.7 \\
$\mathrm{Sampling}(\mathrm{mg}-\mathrm{N})$ & 0 & 137 & 287 & 398 \\
\hline $\mathrm{Sum}(\mathrm{mg}-\mathrm{N})$ & $1.76 \times 10^{3}$ & $1.80 \times 10^{3}$ & $1.75 \times 10^{3}$ & $1.78 \times 10^{3}$ \\
\hline
\end{tabular}




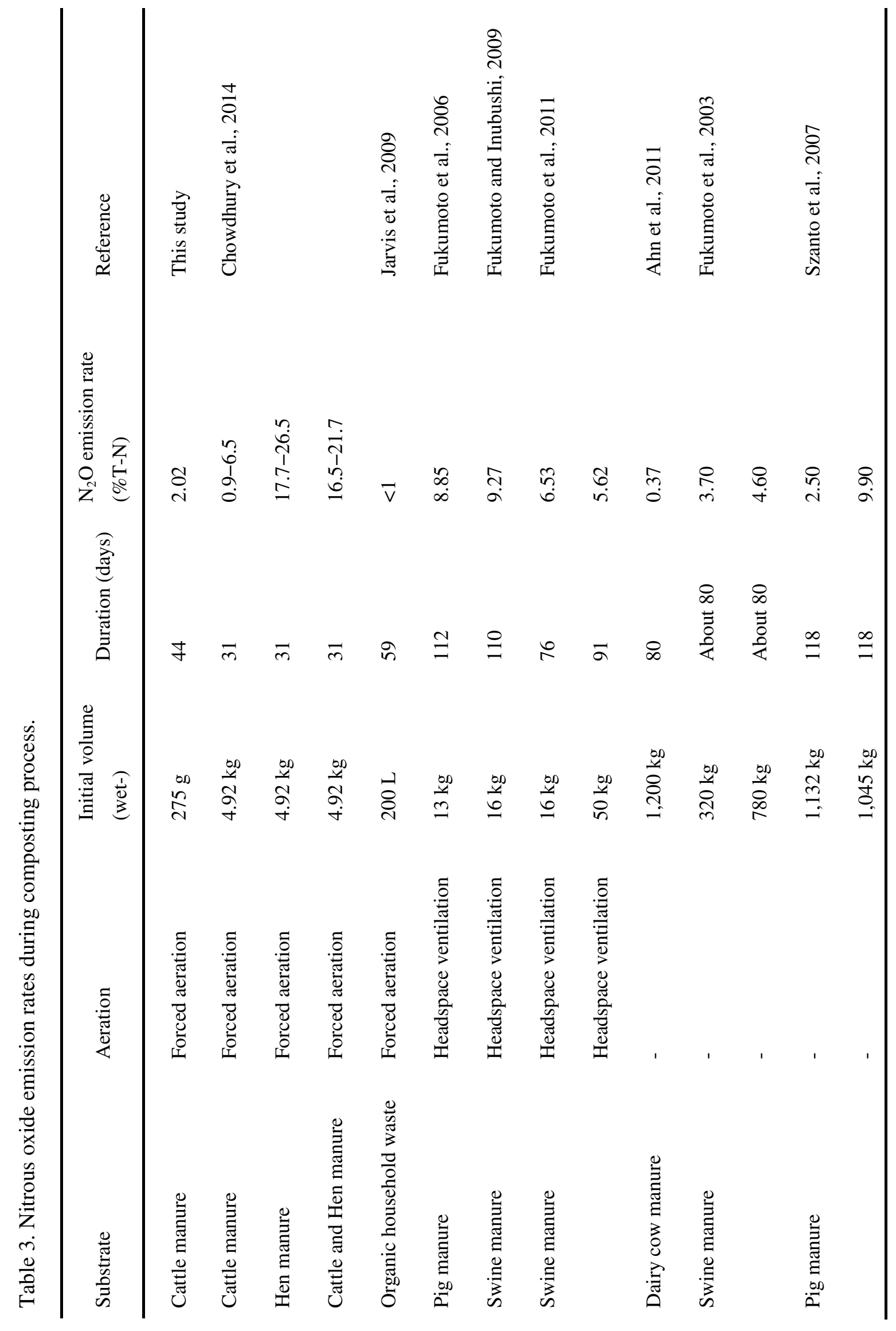


Figure captions

Fig. 1. Oxygen uptake rate (A), $\mathrm{CO}_{2}$ emission rate (B), respiratory quotient $(\mathrm{C})$, and $\mathrm{N}_{2} \mathrm{O}$ emission rate (D) in Experiment I. Values and error bars indicate average and standard deviation in triplicate experiments.

Fig. 2. Temporal shift of correlation plots between respiratory quotient and nitrous oxide emission rates. Symbols represent following time periods: triangle, day 0 through 7; diamond, day 7 through 11; circle, day 11 through 19; square, day 19 onward.

Fig. 3. Change of respiratory quotient values (A) and $\mathrm{N}_{2} \mathrm{O}$ emission rates (B) in Experiment II. Values and error bars indicate average and standard deviation in duplicate experiments. Dotted line in (A) represents moving average $(n=3)$ and line in $(B)$ represents cumulative $\mathrm{N}_{2} \mathrm{O}$ emissions.

Fig. 4. Behavior of inorganic nitrogen in composting samples. Symbols represent the following compounds: diamond, $\mathrm{NH}_{4}{ }^{+}-\mathrm{N}$; square, $\mathrm{NO}_{2}{ }^{-}-\mathrm{N}$; triangle, $\mathrm{NO}_{3}{ }^{-}-\mathrm{N}$. Values and error bars indicate average and standard deviation in duplicate experiments.

Fig. 5. Correlation plots of total concentrations of $\mathrm{NO}_{2}{ }^{-}-\mathrm{N}$ and $\mathrm{NO}_{3}{ }^{-}-\mathrm{N}$, plus $\mathrm{N}_{2} \mathrm{O}$ emission rates.

Fig. 6. Behavior of 16S rRNA genes of eubacteria and amoA genes of AOB in reactors 1 and 2 during Experiment II. Values and error bars indicate average and standard deviation in duplicate measurements. Squares represent 16S rRNA genes of eubacteria, and circles represent amoA genes in AOB. N.D indicates not detected. 

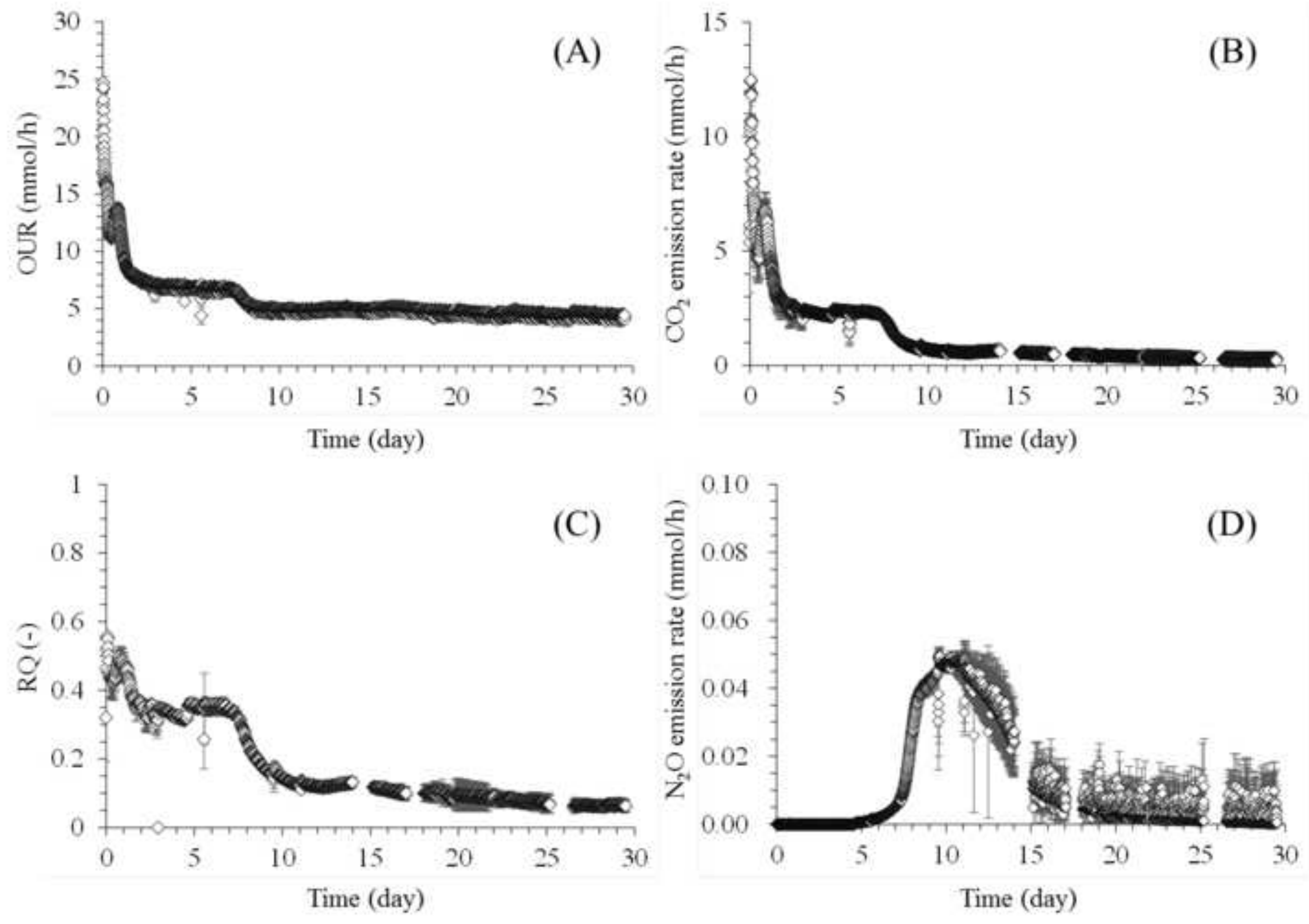


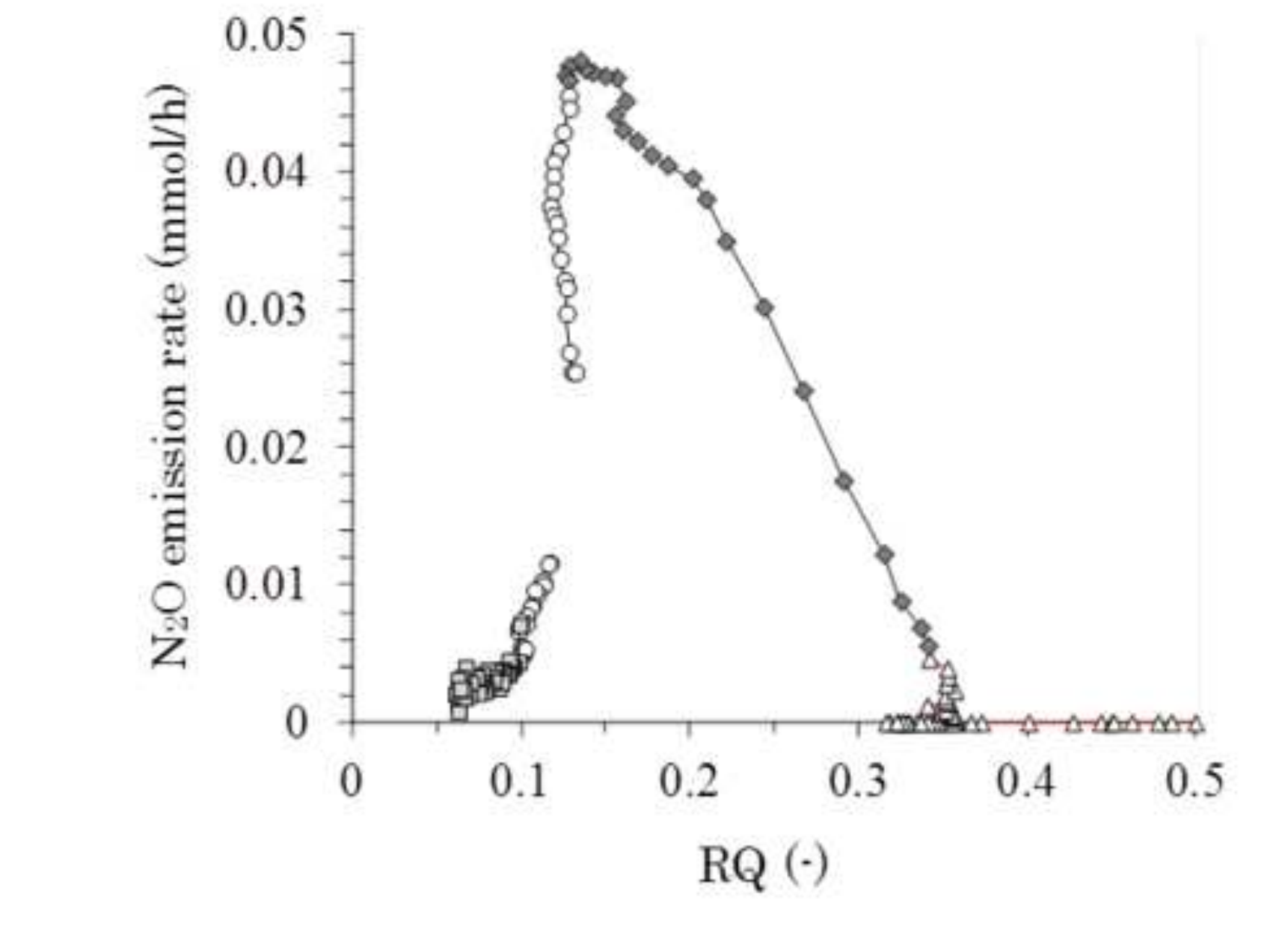

.



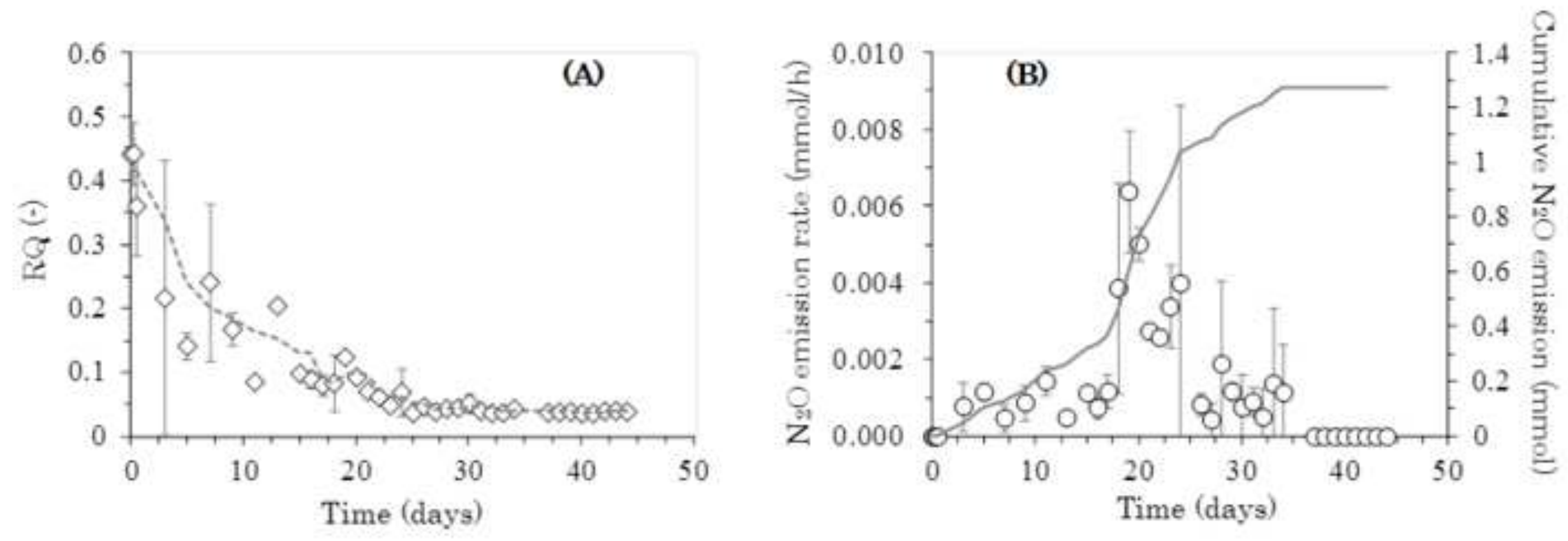


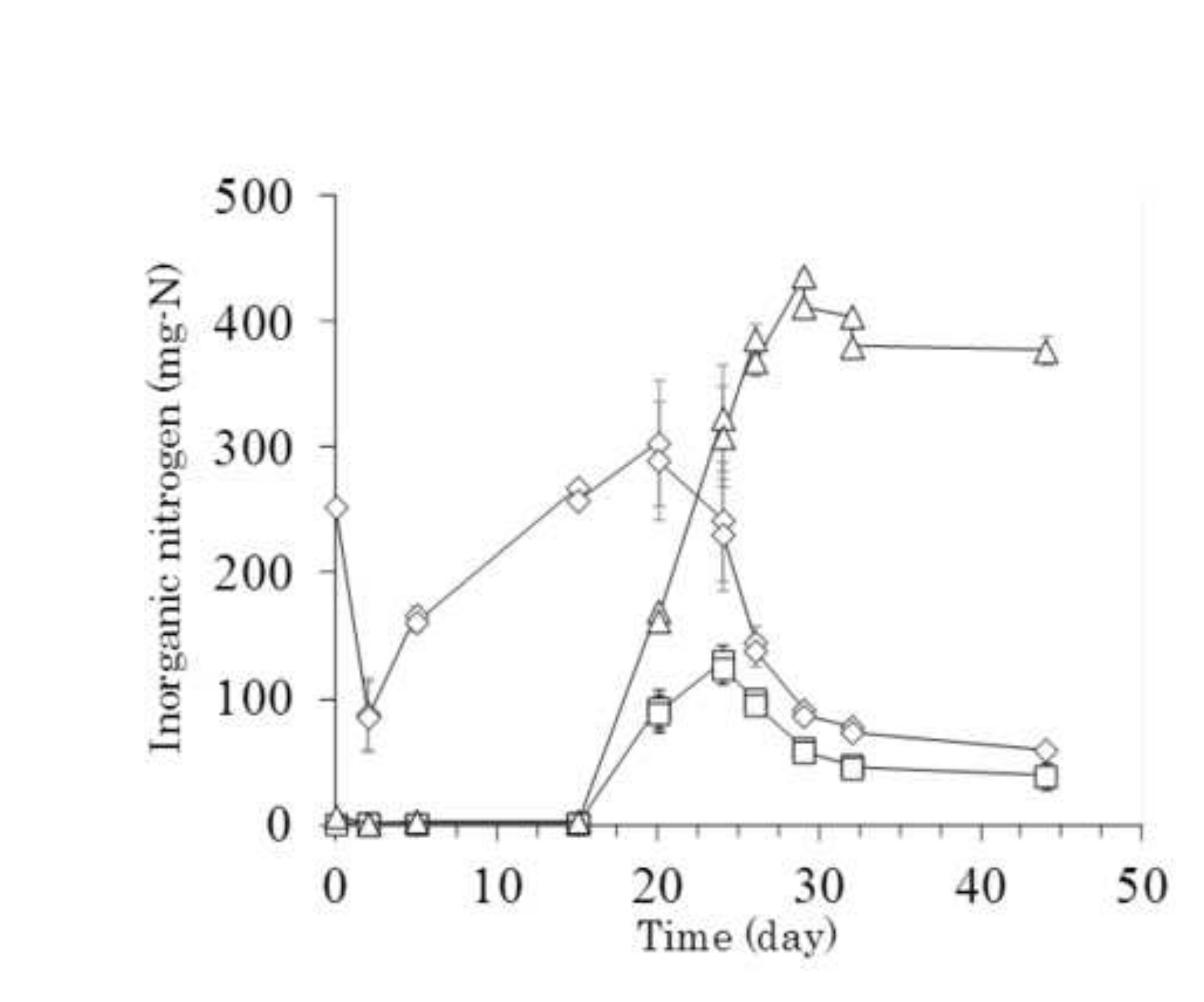

.

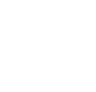

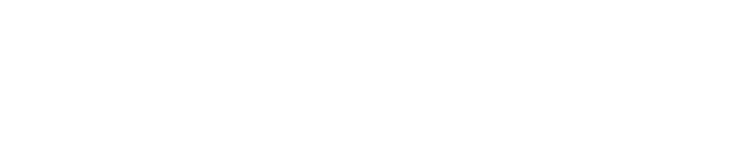

-

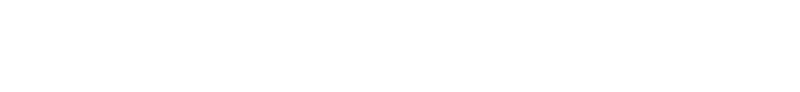

(n)
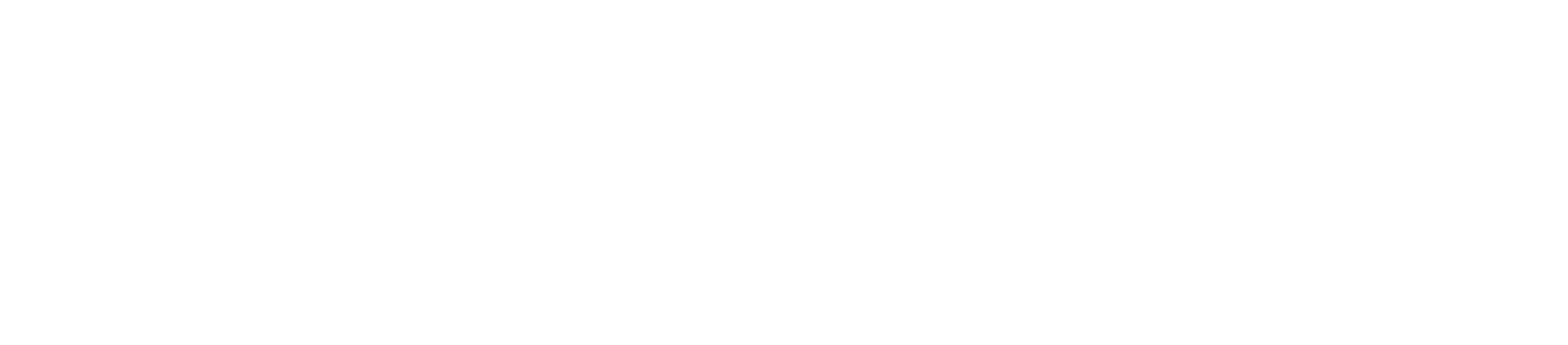

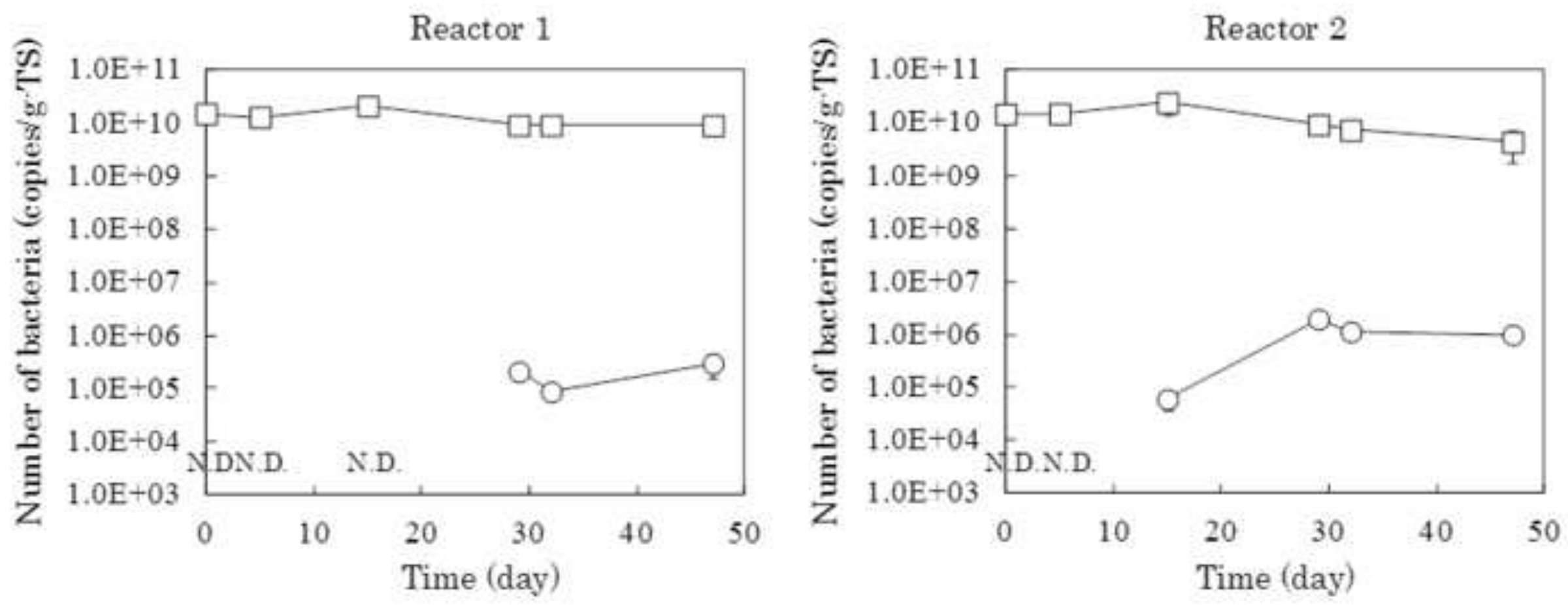